\title{
Ingestion of supplements and fortified food with iodine on the breast milk iodine concentration in deficiency areas: a systematic review
}

\author{
Almeida Abudo Leite Machamba ${ }^{1}$, Silvia Eloiza Priore², Mariana de Souza Macedo ${ }^{3}$, \\ Sylvia do Carmo Castro Franceschini ${ }^{4}$
}

1. Almeida A. L. Machamba: PhD Student in the Postgraduate Program in Nutrition Science, Department of Nutrition and Health, Federal University of Viçosa (UFV), Viçosa, Brazil.

2. Full PhD Professor in the the Postgraduate Program in Nutrition Science, Department of Nutrition and Health, Federal University of Viçosa (UFV), Viçosa, Brazil.

3. Post-Doctoral in the Postgraduate Program in Nutrition Science, Department of Nutrition and Health, Federal University of Viçosa (UFV), Viçosa, Brazil.

4. Full PhD Professor in the the Postgraduate Program in Nutrition Science, Department of Nutrition and Health and Pro-Rector of community affairs, Federal University of Viçosa (UFV), Viçosa, Brazil.

\begin{abstract}
Introduction: The level of iodine in breast milk may be inadequate and compromise the health of this, both due to excess and lack, some population groups remain deficient because of the low consumption of iodate salt, because there is an increase in consumption of other sources of iodine, such as supplements and fortified foods.

Objective: To evaluate the effect of the consumption of fortified foods and nutritional supplements with iodine on maternal milk levels.

Methodology: Systematic review based on the Prism method, using the descriptors provided by DeCS. The reading, selection and analysis of the methodological quality of the articles was done by two researchers independently.

Results: From 346 abstracts, 6 were eligible. The median iodination range between the studies ranged from 75 to $600 \mu \mathrm{g}$ in supplements and 150 and $225 \mu \mathrm{g}$ in fortified foods with effect on increased iodine concentration of breastmilk (BMIC), achieving the adequacy of the median BMIC in 4 of the 6 studies.

Conclusion: Iodine ingestion through supplements or fortified foods results in improved iodine levels in breast milk.

Keywords: Iodine; supplements; fortified foods, breastmilk; iodine concentration.

DOI: https://dx.doi.org/10.4314/ahs.v21i3.46

Cite as: Machamba AAL, Priore SE, de Souza Macedo M, do Carmo Castro Franceschini S. Ingestion of supplements and fortified food with iodine on the breast milk iodine concentration in deficiency areas: a systematic review. Afri Health Sci. 2021;21(3). 1346-1354. bttps:// dx.doi.org/10.4314/abs.v21i3.46
\end{abstract}

\section{Introduction}

The iodine deficiency in the world primarily affects the maternal-infant group, such as lactating women consequently the group less studied ${ }^{1}$. This has serious

\section{Corresponding author:}

Almeida Abudo Leite Machamba,

Department of Nutrition and Health. Ed.

Centro de Ciências Biológicas II, Peter Henry

Rolfs Avenue, w/o. Campus Universitário.

Zip Code: 36570.900 - Viçosa - MG.

Phone number: +55 (31) 3899-2899.

E-mail: almeidamachamba@gmaill.com consequences on women's health, but also impacts the child on breastfeeding, compromising neurocognitive and psychomotor development, and other neurological consequences $^{2,3}$.

The Breast milk is the primary food of the infant in the first 6 months of life, guaranteeing the availability of all the nutrients that the infant needs including iodine. However, the iodine intake by lactating women reflects the contribution of the infant in exclusive breastfeeding. Therefore iodine present in the milk, considered a good indicator of ingestion of this nutrient by the lactating women, because physiologically this in the or- 
ganism, tends to concentrate more on breast milk, by recaptation of iodine present in the cytoplasm through the sodium iodine symporter and output of iodine in mammary gland ${ }^{4}$.

To ensure the infant iodine needs, from 90 to $110 \mu \mathrm{g} /$ day, by the ingestion of $0,78 \mathrm{~L}$ of breast milk ${ }^{5}$, the lactating women need to ingest $250 \mu \mathrm{g} /$ day of this micronutrient, through the consumption of foods, supplements and the iodized salt, ${ }^{1,6-8}$ to maintain their levels on the average of $146 \mu \mathrm{g} / \mathrm{L}$ of breastmilk. And in cases of insufficiency, additional consumption of $150 \mu \mathrm{g} / \mathrm{day}$ of iodine through supplements. This measure is adopted by most part countries through iodation programs and has resulted in positive effects on the reduction of all forms of disorders caused by the deficiency of this mineral ${ }^{9,10}$.

In the world, although some countries have achieved iodine adequate ${ }^{11-13}$, or excessive levels of iodine consumption ${ }^{14-21}$, specific population groups remain deficient or excessive at the same time that they present with low consumption of iodized salt ${ }^{10,13,14,22,23}$, which leads to the hypothesis that this should be consumed in other food sources, such as fortified foods and iodine supplements. Thus, the levels of this micronutrient in breast milk may be inadequate and compromise the infant's health, both due to excess and lack ${ }^{24}$.

As the recommendations for reducing salt consumption in many countries have been observed as protection measures against the occurrence of chronic diseases non-communicable. Thus, alternatively, the use of fortified foods or the supplementation has been verified many times associated with change of iodine status in population $^{11}$. On the other hand, there is little availability of studies evaluating the impact of consumption of fortified foods and iodine supplements on the variation of levels in breast milk in lactating women, which justifies this review. The objective is to evaluate the effect of the consumption of fortified foods and nutritional supplements with iodine on iodine levels in breast milk.

\section{Methodology}

A systematic review was conducted, based on the Preferred Reporting Items for Systematic Reviews (PRISMA ${ }^{25}$ methodology to select articles. This systematic review sought to answer the following question "what's the change of the level of iodine in breastmilk of lactating women who receive supplements or foods fortified with iodine?" The protocol of this study was registered in the PROSPERO with the identification number CRD42019122219.

The research was conducted from September 1st of 2018 to April 30st of 2019. To identify the articles, we conducted the search in MEDLINE (Pubmed), Science Direct, Scopus databases and Cochrane Library. Using the descriptors: "Iodine AND drugs OR supplementation AND breast milk iodine concentration AND urinary iodine concentration", "Iodine AND iodine supplementation AND iodine fortification OR foods OR condiments OR dietary supplements OR food fortified OR food consumption AND breast milk iodine concentration AND urinary iodine concentration": provided by DeCS (an acronym for Descriptores en Ciencias de la Salud: Health Sciences Descriptors) in English, Portuguese and Spanish, without filters.

For inclusion criteria original articles were included from randomized clinical studies, cohort and case-control that focus effect of maternal iodine intake, present in nutritional supplements and/or fortified foods in breastfeeding period on breast milk iodine concentratin. Studies were chosen if: i) participants received iodine supplements or fortified foods and ii) an appropriate control group was included which comprised participants who either received no supplements or fortified foods iii) all participants had to be breast milk iodine concentration with outcomes.

By two independent researchers the articles were selected after finishing elimination of duplicities by database and among databases. . In the case of divergencies, a third author was invited to include or discard. Information was extracted from the year, authorship, place of the study, type of design, target population, sample size, type, dose and duration of ingestion of the supplement and/or the fortified food, amount of iodine in the supplements, fortified food, breast milk and urine.

The quality of the studies were assessed according to the type of the study, therefore randomized clinical trials were assessment with Jadad et al. method ${ }^{26}$. Studies were graded as high, moderate and low quality according to specific scores on the randomisation procedure, blinding of participants and investigators, and withdrawal rates from the study. Another studies (case-control and cohort) by Newcastle-Ottawa scale ${ }^{27,28}$. Points were awarded for each study as follows: maximum of 
4 for study selection, 2 for comparability and 4 for exposure or outcome. Based on total scores, studies were graded as high (9-10 points), moderate (7-8 points) or low ( $<7$ points) quality.

Although some articles were of low quality, because they were published in high-impact journals, the authors included in the study.

\section{Results}

The search resulted in 346 articles, after the elimination of duplicates, reading of titles, abstracts and full tests, 6 were selected (Figure 1). The studies were excluded because they failed to meet the inclusion criteria.

The studies were developed in countries of the African, European, American, Asian and Oceania continents and dated from 1999 to 2017. Regarding the design, three were randomized clinical trials 19, 27, 30, two cohort 10,17 and one case-control 29 (Chart 1).

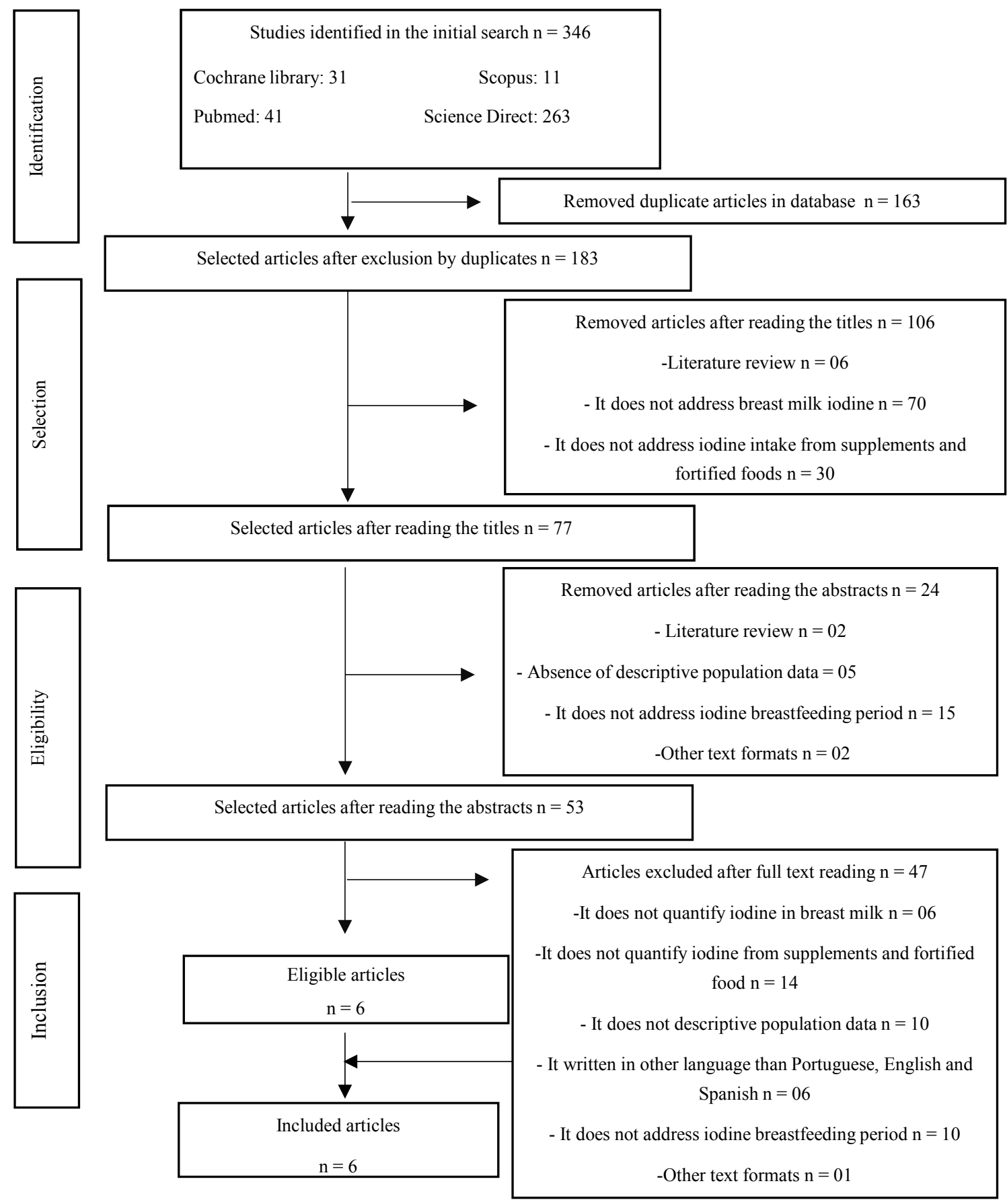

Figure 1. Identification and selection of articles. 
Chart 1. Characteristics of studies of the ingestion of supplementation and iodine fortification in lactating women.

\begin{tabular}{|c|c|c|c|c|c|c|c|}
\hline $\begin{array}{c}\text { Place of } \\
\text { estudy } \\
\text { (reference) }\end{array}$ & Study design & $\mathrm{n}$ & $\begin{array}{l}\text { Region and } \\
\text { social status }\end{array}$ & Product/application & $\begin{array}{l}\text { Iodine } \\
\text { content }\end{array}$ & $\begin{array}{l}\text { Iodine } \\
\text { recommendation }\end{array}$ & $\begin{array}{l}\text { Intervention } \\
\text { time }\end{array}$ \\
\hline Italy ${ }^{29}$ & Case-control & 22 & $\begin{array}{l}\text { Urban } \\
>\text { SEL }\end{array}$ & $\begin{array}{l}\text { 1 PerMamma } \\
\text { Abbott } \% \text { day }\end{array}$ & $116 \mu \mathrm{g} \mathrm{KI}$ & $290 \mu{\mathrm{g} \mathrm{I} / \text { day }^{31}}^{31}$ & 3 days \\
\hline $\begin{array}{c}\text { New } \\
\text { Zealand }{ }^{27}\end{array}$ & $\begin{array}{l}\text { Randomized } \\
\text { clinical trial }\end{array}$ & 84 & Urban & 1 table/day & $\begin{array}{l}75-150 \mu \mathrm{g} \\
\mathrm{KIO} 3\end{array}$ & $150 \mu \mathrm{g} \mathrm{I} /$ day $^{32}$ & 168 days \\
\hline $\begin{array}{l}\text { United } \\
\text { States }{ }^{10}\end{array}$ & $\begin{array}{c}\text { Prospective } \\
\text { cohort }\end{array}$ & 16 & Urban & $\begin{array}{c}2 \text { tablets/day } \\
+ \\
2 \text { pills/day }\end{array}$ & $\begin{array}{c}2 \times 75 \mu \mathrm{g} \\
\mathrm{KI} \\
2 \times 225 \mu \mathrm{g} \\
\mathrm{KI}\end{array}$ & $150 \mu \mathrm{g} \mathrm{I} /$ day $^{32}$ & 1 day \\
\hline Australia ${ }^{17}$ & $\begin{array}{c}\text { Prospective } \\
\text { cohort }\end{array}$ & 944 & Urban & 1 pill/day & $150 \mu \mathrm{g} \mathrm{KI}$ & $150 \mu \mathrm{g} \mathrm{I} /$ day & 141 days \\
\hline Ethiopia ${ }^{19}$ & $\begin{array}{l}\text { Randomized } \\
\text { clinical trial }\end{array}$ & 101 & $\begin{array}{l}\text { Rural, } \\
>\text { SEL }\end{array}$ & $\begin{array}{l}1 \mathrm{pill} / \text { day } \\
10.3 \mathrm{~g} \text { of iodized } \\
\text { salt } / \text { day }\end{array}$ & $\begin{array}{c}225 \mu \mathrm{g} \mathrm{KI} \\
30-40 \mu \mathrm{g} \\
\text { KIO3 }\end{array}$ & $\begin{array}{c}225-350 \mu \mathrm{g} \\
\mathrm{I} / \text { day }^{33}\end{array}$ & 183 days \\
\hline $\operatorname{Iran}^{30}$ & $\begin{array}{l}\text { Randomized } \\
\text { clinical trial }\end{array}$ & 84 & Urban & $\begin{array}{l}200 \mathrm{~mL} \text { of cow } \\
\text { milk/day }\end{array}$ & $150 \mu \mathrm{g} \mathrm{KI}$ & $150 \mu \mathrm{g} \mathrm{I} /$ day $^{28}$ & 28 days \\
\hline
\end{tabular}

In this review, the samples number ranged from one 17 study with small sample size of 16 and other one with large of $994^{27}$ lactating women, supplemented with capsules, tablets and nutritional solutions of potassium iodide (KI), with doses that ranged from $75 \mu \mathrm{g} 10$ a 600 $\mu \mathrm{g} 17$ daily and food intake like bread 19 and milk, a part form iodized salt ${ }^{10,17,19}$, that were fortified with KI and potassium iodate (KO3). All administrations start between the 1 st to 183 days (Chart 1$)$.

In all the studies, the effect of iodine intake for lactating women on breast milk levels and in your urine (Chart 2) were presented.

Regarding the quality analysis of the studies, we observed that three ${ }^{10,19,29}$ were classified as low quality, two ${ }^{17,30}$ moderate and one ${ }^{27}$ high. 
Chart 2. Change from breast milk iodine concentration (BMIC) and urine iodine concentration (UIC) of the lactating women who consumed iodine supplements and/or fortified foods.

\begin{tabular}{|c|c|c|c|c|}
\hline $\begin{array}{c}\text { Place of } \\
\text { estudy } \\
\text { (reference) }\end{array}$ & Cut-off points & Interventions & $\%$ of changes from BMIC in $\mu \mathrm{g} / \mathrm{L}$ & $\begin{array}{l}\% \text { of changes from UIC in } \\
\mu \mathrm{g} / \mathrm{L}\end{array}$ \\
\hline Italy 29 & $\begin{array}{c}\text { BMIC: } 110 \pm 40 \\
\mu \mathrm{g} / \mathrm{L}\end{array}$ & $\begin{array}{c}116 \mu \mathrm{g} \mathrm{KI} / \text { day }(\mathrm{n}=10) \\
\text { Control }(\mathrm{n}=12)\end{array}$ & $\begin{array}{l}\uparrow \text { mean in } 3 \text { days of intervention, with } \\
\text { more } 50 \mu \mathrm{g} \text { in KI group, achieving } \\
\text { adequacy in the } 2 \text { groups, but at } 90^{\circ} \text { day } \\
\text { of measurement there were } \downarrow \text { in } 75.0 \% \\
\text { in KI group and in } 59.3 \% \text { in control } * \text {. }\end{array}$ & NA \\
\hline $\begin{array}{c}\text { New } \\
\text { Zeland }{ }^{27}\end{array}$ & $\begin{array}{c}\mathrm{UIC}: 290 \mu \mathrm{g} / \mathrm{L} \\
\mathrm{BMIC}:>114 \\
\mu \mathrm{g} / \mathrm{L}^{34}\end{array}$ & $\begin{array}{c}75-150 \mu \mathrm{g} \mathrm{KIO} / \text { day } \\
(\mathrm{n}=40) \\
\text { Control }(\mathrm{n}=44)\end{array}$ & $\begin{array}{c}\uparrow \text { median of } 6.3 \% \text { with } 75 \mu \mathrm{g} \text { I/day up } \\
\text { to } 168^{\circ} \text { day* and } 23.1 \% \text { with } 150 \\
\mu \mathrm{g} / \text { day up to } 28^{\circ} \text { day } \dagger \text {, and } \downarrow \text { up to } 40 \% \\
\text { in Control } \uparrow . \text { Not adequated. }\end{array}$ & $\begin{array}{l}\uparrow \text { in median at } 168^{\circ} \text { day in } \\
122,9 \% \text { with } 75 \mu \mathrm{g} \mathrm{I} / \text { day } \dagger \text {, } \\
\quad 68 \% \text { with } 150 \mu \mathrm{g} \\
\mathrm{I} / \text { day* and } 70 \% \text { in } \\
\text { controlo } \dagger . \text { Not adequated. }\end{array}$ \\
\hline $\begin{array}{l}\text { United } \\
\text { States }{ }^{10}\end{array}$ & $\begin{array}{c}\text { BMIC: } 110 \\
\mu \mathrm{g} / \mathrm{L}^{35}\end{array}$ & $600 \mu \mathrm{g} \mathrm{KI} /$ day $(\mathrm{n}=16)$ & $\begin{array}{c}\uparrow \text { median of } 516.5 \% \text { from } 1^{\text {st }} \text { to the } \\
8^{\text {th }} \text { hours of measurement, but at } 678.0 \% \\
\text { at the peak reached in the } \\
6^{\text {th }} \text { hour } \dagger \text {. Achieving adequacy. }\end{array}$ & $\begin{array}{c}\uparrow \text { in median of } 184.4 \% \text { in } \\
\text { the } 8^{\text {th }} \text { hour of measurement, } \\
\text { achieving adequacy. }\end{array}$ \\
\hline Australia $^{17}$ & $\begin{array}{c}\mathrm{BMIC} \geq 100 \\
\mu \mathrm{g} / \mathrm{L}^{36}\end{array}$ & $\begin{array}{c}150 \mu \mathrm{g} \mathrm{KI} / \text { day }+ \\
\text { iodized bread } \\
(\mathrm{n}=588) \\
150 \mu \mathrm{KI} / \text { day }+ \text { bread } \\
(\mathrm{n}=136) \\
\text { Control, Iodized bread } \\
(\mathrm{n}=65) \\
\text { Bread }(\mathrm{n}=155)\end{array}$ & $\begin{array}{c}\uparrow \text { in the median of } 95.0 \% \text { in the } \\
\text { group } \uparrow \text { and } 28.6 \% \text { in Control } \uparrow \text {, and } \\
\text { both adequate. }\end{array}$ & NA \\
\hline Ethiopia ${ }^{19}$ & $\begin{array}{c}\mathrm{UIC}>100 \mu \mathrm{g} / \mathrm{L} \\
\mathrm{BMIC}: 146 \\
\mu \mathrm{g} / \mathrm{L}^{34}\end{array}$ & $\begin{array}{l}225 \mu \mathrm{g} \mathrm{KI} / \text { day }(\mathrm{n}=51) \\
\text { Control: } \\
10,3 \mathrm{~g} \text { iodized salt/day } \\
\quad(30-40 \mu \mathrm{g} \\
\mathrm{KIO} / \mathrm{g} \text { of salt })(\mathrm{n}=50)\end{array}$ & $\begin{array}{c}\downarrow \text { in the median of } 30.2 \% \text { in the KI } \\
\text { group and } 29.3 \% \text { in Control, and both } \\
\text { becoming inadequate according to the } \\
\text { authors, but had a value above } 100 \\
\mu \mathrm{g} / \mathrm{L} .\end{array}$ & $\begin{array}{l}\uparrow \text { in the median of } 10.3 \% \text { in } \\
\text { teh KI group and in } 5.3 \% \text { in } \\
\text { control, and both remain in } \\
\text { adequate. }\end{array}$ \\
\hline $\operatorname{Iran}^{30}$ & $\begin{array}{c}\text { UIC: } \geq 100 \mu \mathrm{g} / \mathrm{L}^{4} \\
\text { BMIC: } 150-180 \\
\quad \mu \mathrm{g} / \mathrm{L}^{37}\end{array}$ & $\begin{array}{l}\text { 200mL iodized cow } \\
\text { milk }(150 \mu \mathrm{g} \mathrm{KI} / \text { day }) \\
(\mathrm{n}=42) \\
\text { Control }(\mathrm{n}=42)\end{array}$ & $\begin{array}{c}\uparrow \text { in the median of } 37.5 \% \text { in the } \mathrm{KI} \\
\text { group } * \text {, achieving adequacy and } \downarrow \text { in } \\
25.6 \% \text { in Control*, not achieving } \\
\text { adequacy. }\end{array}$ & $\begin{array}{l}\uparrow \text { in the median of } 48.3 \% \text { in } \\
\text { the KI group*, achieving } \\
\text { adequacy and } \downarrow \text { in } 57.2 \% \text { in } \\
\text { the control*, Not adequated. }\end{array}$ \\
\hline
\end{tabular}

\section{Discussion}

\section{Supplementation}

The supplementation in lactating women results in the improvement of iodine levels in breast milk, regardless of the administered dose and duration of supplementation.

It was possible to observe that supplementation with, $600 \mu \mathrm{g} \mathrm{KI}$ in 1 day $(\mathrm{P}<0.001) 10$ and $150 \mu \mathrm{g} \mathrm{KI} /$ day in 28 days $(\mathrm{P}=0,001)^{27}$, altered the levels of iodine in breast milk, improving the content and making them adequate.

The correction of low iodine levels in breast milk to adequate in lactating women who presented iodine insufficiency, showed that supplementation and consumption of fortified foods as an effective practice for restoring adequate levels of breast milk (chart 1 and 2).

However, supplementation with iodine values below $150 \mu \mathrm{g}$ daily in moderately deficient lactating women did not result in a change ${ }^{27}$, but when theses supplemented at $150 \mu \mathrm{g}$ the deficiency status changed to mild ${ }^{29}$.

In a study developed in Italy, where it was offered to lactating women with iodine deficiency, for 3 days of hospital treatment, one PerMamma Abbott $\mathbb{C}$ pharmaceutical solution per day that contained $116 \mu \mathrm{g}$ of iodine, having reached iodine adequacy in breast milk in third day but don't have change for control group. The authors showed a reduction of their iodine levels after 3 months, becoming inadequate, when compared to other lactating women who were also submitted to hospital treatment but who maintained only usual consumption of food fortified with iodine ${ }^{29}$.

However, it is noticed that the supplemented dose was lower than the Food Drug Administration (FDA), which recommends that this should be done with $150 \mu \mathrm{g} \mathrm{I} /$ day for each nursing mother. Thus, it was understood that supplementation, with levels $>100$ and $<150 \mu \mathrm{g}$ $\mathrm{I} /$ day is successful in the acute treatment of deficiency for the quick replacement of iodine levels in breast milk, but for long-term maintenance, the consumption of fortified foods seems to be more effective ${ }^{3}$. On the other hand, in first days after deliver iodine supplementation or your intake for fortified foods not had impact 
in breast milk because in this time iodine breast milk concentration is stable ${ }^{24}$.

Still, supplementation with $150 \mu \mathrm{g} \mathrm{I} /$ day, is criticized by some authors, who claim that it is not enough to correct the severe or moderate deficiency of iodine in lactating women ${ }^{38}$. The Institute of Medicine of the United States (IOM) recommends that the best, is to practice a nutrient-rich diet that is balanced and varied diet over the days beyond only the use of supplements with iodine 39,40 , in the ingestion of iodine, it is important to have all the factors related to the ingestion of food and beverages that may influence the nutritional contribution of iodine in the lactating women ${ }^{9,10}$.

\section{Fortification}

The consumption of iodine has been facilitated by the availability of fortified foods, as it is not available in the natural form.

It was possible to observe intake of $150 \mu \mathrm{g} \mathrm{KI} /$ day during 124 days, the fortified foods consumption such as iodized bread ${ }^{17}$ and for 28 days the fortified milk $(\mathrm{P}<$ 0.05) 14 that change the levels of iodine in breast milk and making them adequate.

This strategy has been widely adopted as a measure of nutritional availability in iodine in many countries of the European, American and Oceania continents. So although salt consumption is recommended to adapt iodine levels, this has been related to the occurrence of non-communicable diseases $(\mathrm{NCDs})^{18,41}$.

Newer studies have shown that the amount of salt ingested brings more risks related to NCDs, than benefits related to the supply of iodine ${ }^{3,18,41}$. Reason why many European and Australia countries have been adopting programs to reduce salt ingestion in the population. Thus, the consumption of fortified foods with iodine, such as milk and its derivatives has been adopted in Europe and Asia ${ }^{17,42}$, bread in Oceania, Asia and Europe 10. This makes a measure of change of the food vehicle but also of the promotion of iodine consumption, as iodine is made available in other foods more pleasured and appreciated by the population. However, the monitoring of the iodine content to be supplemented in food is crucial.

\section{Clinical interpretation}

Supplementation with high doses of iodine not only restores the iodine quickly but also corrects the deficien- cy, 38 even so it is recommended in severe to moderate iodine deficiency in lactating women with unavailability of foods rich in iodine in the diet ${ }^{43}$.

According to FDA, KI should be used in the formulations of supplements and KIO3 in fortified foods, specifically to salt $3,18,41$, however, in European countries such as Norway, Iceland and other Nordic countries, there are more than 20 formulations of dairy products fortified with iodine ${ }^{9,10}$. However, without any iodine reference approved by the FDA, which makes pertinent the existence of an international iodine reference and not only national for the fortification of food with iodine. Although, according to the Iodine Global Network, the type of iodine to be incorporated in food is not important, as well as the forms provide the amount of sufficient iodine that the body needs, although it is pointed out that the preference of the countries for using $\mathrm{KI}$, is its low cost that is associated with its large production in the world ${ }^{44}$. Meanwhile, the definition and approval of the vehicles to be incorporated is that it is the real concer, taking into account that each country has its eating habits.

The World Health Organization (WHO) indicates that the consumption of $250 \mu \mathrm{g}$ of iodine per day by the lactating women is able to guarantee its concentration around $140 \mu \mathrm{g} / \mathrm{L}$ in breast milk, which keeps the iodine reserves for the infant. However, it was found that there are no reference values of iodine that classify the deficiency, adequacy or excessive amount in breast milk.

How alternative of salt reductions WHO recommends the consumption of 2 cups of milk ( $400 \mathrm{ml})$ Daily, to provide $250 \mu \mathrm{g}$ of iodine 45 , In this study a cup of $200 \mathrm{ml}$ of milk per day was used to provide $150 \mu \mathrm{g}$ of iodine, which makes the iodized milk a sufficient food source to satisfy the lactating women.

Although, as a policy of public health intervention, food fortification is the most effective and practical for the prevention of this deficiency ${ }^{45}$.

However, the practice of supplementation should be considered in iodine insufficiency in lactating women, resulting from low coverage of adequate iodized salt in household, failed iodization programs, greater concern to reduce salt consumption or unavailability of food fortified with iodine beyond salt ${ }^{46}$. Nevertheless, fortified foods emerge as an alternative to reduce salt consumption and increase iodine consumption, so peo- 
ple should be aware that its benefits are obtained in the medium and long-term.

The lack of an international reference value of iodine in fortified foods, besides salt in addition to the absence of an international reference for iodine in breast milk and its classification, which constituted a considerable limitation in this study and area of research, as it is difficult to discuss and compare data. On the other hand, by obtaining studies of at least one country from each continent, it allowed us to understand how the problem is global.

\section{Final Remarks}

Supplementation results in improved iodine levels in breast milk. However, the iodine doses above 100 and below $150 \mu \mathrm{g} /$ day are not adequate for iodine levels, but doses above $150 \mu \mathrm{g}$ change the levels of deficiency. And this effect is the same when consuming fortified foods, and both (supplements and fortified foods) establish and remain in the body for long time.

In acute treatment in severe to moderate insufficiency conditions, supplementation with iodine doses of 600 $\mu \mathrm{g}$ nursing mother was effective in the daily iodine replacement in breast milk, which became adequate.

Further studies are required to verify the effect of supplementation and consumption of fortified foods with lower doses to restore iodine levels in breast milk as well as to establish cut off points for BMIC.

\section{Conflict of interest}

Nothing to declare.

\section{Funding}

This work was supported by the Funding Agency 01: Coordination of Improvement of Higher Education Personnel - Brazil (CAPES) - Financing Code 001. Funding Agency 02: National Council for Scientific and Technological Development $(\mathrm{CNPq})$, case 408295/2017-1. Funding Agency 03: Foundation of Support and Research of the State of Minas Gerais (FAPEMIG) case APQ-03336-18.

\section{Authors contribution}

Search and selection of articles: MACHAMBA, A.A.L. write full test: MACHAMBA, A.A.L. Critical elaboration of the text: PRIORE, SILVIA E.; MACEDO, M. S.; Critical elaboration of the text and approved the final version: FRANCESCHINI, S.C.C.

\section{Acknowledgements}

This work was conducted through the support of the Coordination of Improvement of Higher Education Personnel - Brazil (CAPES) - Financing Code 001 through scholarships for postgraduate students.

We thank to the National Council for Scientific and Technological Development (CNPq), case 408295 / 2017-1 and the Foundation for Support and Research of the State of Minas Gerais (FAPEMIG), case APQ03336-18.

\section{References}

1. Małgorzata Gizak, Human Nutrition Laboratory, ETH Zurich, IGN. Global Scorecard 2016: Moving toward Optimal Iodine Status. Iodine Global Network. Ottawa, Canada: Iodine Global Network; 2016. p. 4.

2. Andersen SL, Moller M, Laurberg P. Iodine concentrations in milk and in urine during breastfeeding are differently affected by maternal fluid intake. Thyroid. 2014 Apr;24(4):764-72.

3. Stoutjesdijk E, Schaafsma A, Dijck-Brouwer DAJ, Muskiet FAJ. Iodine status during pregnancy and lactation: a pilot study in the Netherlands. Netherlands Journal of Medicine. 2018 Jul;76(5):210-7.

4. World Health Organization, United Nations Children's Fund, Disorders ICfCoID. Assessment of iodine deficiency disorders and monitoring their elimination: A guide for programme managers, Third edition (updated 1st September 2008). World Health Organization,. Geneva, Switzerland: World Health Organization; 2007. p. 98.

5. Bates CJ, Prentice A. Breast milk as a source of vitamins, essential minerals and trace elements. Pharmacology and Therapeutics. 1994 1994/01/01/;62(1):193-220.

6. Nom-008-ssA2-1993 NOM. Control de la nutrición, crecimiento y desarrollo del niño y del adolescente. Criterios y procedimientos para la prestación del servico. Dayrio Oficial de la Federación. 1994-07 oct;58:28;203.

7. Fund UNCs. The state of the world s children 2015: Executive Summary. United Nations Children's Fund. New York, United States: United Nations Children's Fund; 2015. p. 164.

8. Mary Arimond, Doris Wiesmann, Elodie Becquey, Alicia Carriquiry, Melissa C. Daniels, Megan Deitchler, et al. Simple Food Group Diversity Indicators Predict Micronutrient Adequacy of Women's Diets in 5 Diverse, Resource-Poor Settings1,2,3,4,5,6,7. American Society for Nutritional Sciences. 2010 2004/2/08 11(140):2059S-69S. 9. Nazeri P, Dalili H, Mehrabi Y, Hedayati M, Mirmiran P, Azizi F. Breast Milk Iodine Concentration Rather 
than Maternal Urinary Iodine Is a Reliable Indicator for Monitoring Iodine Status of Breastfed Neonates. Biol Trace Elem Res. [Article In Press]. 2018:1-7.

10. Leung AM, Braverman LE, He X, Heeren T, Pearce EN. Breastmilk iodine concentrations following acute dietary iodine intake. Thyroid. [Article]. 2012;22(11):1176-80.

11. de Lima LF, Barbosa Júnior F, Navarro AM. Excess iodinuria in infants and its relation to the iodine in maternal milk. J Trace Elem Med Biol. 2013 2013/07/01/;27(3):221-5.

12. Brasil MdSd. PNAISal - Pesquisa Nacional de Iodação do Sal Ministério da Saúde do Brasil. Brasília, Brasil: Ministério da Saúde; 2011. p. 01.

13. Rhee SS, Braverman LE, Pino S, He X, Pearce EN. High iodine content of Korean seaweed soup: a health risk for lactating women and their infants? Thyroid. 2011 Aug;21(8):927-8.

14. Picciano MF, McGuire MK. Use of dietary supplements by pregnant and lactating women in North America. The American Journal of Clinical Nutrition. 2009;89(2):663S-7S.

15. Nøhr SB, Lawberg P, Børlum K-G, Pedersen KM, Johannesen PL, Damm P, et al. Iodine status in neonates in Denmark: regional variations and dependency on maternal iodine supplementation. Acta Paedaytr. 1994;83(6):578-82.

16. Huynh D, Condo D, Gibson R, Muhlhausler B, Ryan P, Skeaff $S$, et al. Iodine status of postpartum women and their infants in Australia after the introduction of mandatory iodine fortification. British Journal of Nutrition. 2017;117(12):1656-62.

17. Huynh D, Condo D, Gibson R, Makrides M, Muhlhausler B, Zhou SJ. Comparison of breast-milk iodine concentration of lactating women in Australia pre and post mandatory iodine fortification. Public Health Nutrition. [Article]. 2017;20(1):12-7.

18. Henjum S, Lilleengen MA, Aakre I, Dudareva A, Gjengedal LE, Meltzer MH, et al. Suboptimal Iodine Concentration in Breastmilk and Inadequate Iodine Intake among Lactating Women in Norway. Nutrients. 2017;9(7).

19. Gebreegziabher T, Stoecker BJ. Comparison of two sources of iodine delivery on breast milk iodine and maternal and infant urinary iodine concentrations in southern Ethiopia: A randomized trial. Food Science and Nutrition. [Article]. 2017;5(4):921-8.

20. Butts AC, Hedderley ID, Herath DT, Paturi G, Glyn-Jones S, Wiens F, et al. Human Milk Composition and Dietary Intakes of Breastfeeding Women of Different Ethnicity from the Manawatu-Wanganui Region of New Zealand. Nutrients. 2018;10(9).
21. Axford S, Charlton K, Yeatman H, Ma G. Improved iodine status in breastfeeding women following mandatory fortification. Aust N Z J Public Health. 2011;35(6):579-80.

22. Urban G, Wnek M, Bazowska G. Iodine suplementation during pregnancy and its influence on the newborn. Ginekol Pol. 2000;71(8):690-4.

23. Bouhouch RR, Bouhouch S, Cherkaoui M, Aboussad A, Stinca S, Haldimann M, et al. Direct iodine supplementation of infants versus supplementation of their breastfeeding mothers: a double-blind, randomised, placebo-controlled trial. Lancet Daybetes Endocrinol. 2014 Mar;2(3):197-209.

24. Liberati A, Altman DG, Tetzlaff J, Mulrow C, Gøtzsche PC, Ioannidis JPA, et al. The PRISMA statement for reporting systematic reviews and meta-analyses of studies that evaluate healthcare interventions: explanation and elaboration. British Medical Journal. 2009;339(jul21 1):b2700-b.

25. Jadad AR, Moore RA, Carroll D, Jenkinson C, Reynolds DJM, Gavaghan DJ, et al. Assessing the quality of reports of randomized clinical trials: Is blinding necessary? Controlled Clinical Trials. 1996 1996/02/01/;17(1):1 12.

26. Stang A. Critical evaluation of the Newcastle-Ottawa scale for the assessment of the quality of nonrandomized studies in meta-analyses. Eur J Epidemiol. 2010 2010/09/01;25(9):603-5.

27. Mulrine HM, Skeaff SA, Ferguson EL, Gray AR, Valeix P. Breast-milk iodine concentration declines over the first 6 mo postpartum in iodine-deficient women. American Journal of Clinical Nutrition. [Journal Article; Randomized Controlled Trial; Research Support, NonU.S. Gov't]. 2010;92(4):849-56.

28. Stagnaro-Green A, Abalovich M, Alexander E, Azizi F, Mestman J, Negro R, et al. Guidelines of the American Thyroid Association for the daygnosis and management of thyroid disease during pregnancy and postpartum. Thyroid: official journal of the American Thyroid Association. 2011;21(10):1081-125.

29. Chierici R, Saccomandi D, Vigi V. Dietary supplements for the lactating mother: Influence on the trace element content of milk. Acta Paedaytrica, International Journal of Paedaytrics, Supplement. [Conference Paper]. 1999;88(430):7-13.

30. Nazeri P, Mirmiran P, Tahmasebinejad Z, Hedayati M, Delshad H, Azizi F. The Effects of Iodine Fortified Milk on the Iodine Status of Lactating Mothers and Infants in an Area with a Successful Salt Iodization Program: A Randomized Controlled Trial. Nutrients. 2017 Feb 22;9(2).

31. Umana SIdN. IV Revisione dei Livelli di Assunzione 
di Riferimento di Nutrienti ed energia per la popolazione italiana (LARN) In: (SINU) LSIdNU, editor. Società Italiana di Nutrizione Umana. Milano, Italia: Società Italiana di Nutrizione Umana; 1996. p. 50.

32. Becker DV, Braverman LE, Delange F, Dunn JT, Franklyn JA, Hollowell JG, et al. Iodine Supplementation for Pregnancy and Lactation-United States and Canada: Recommendations of the American Thyroid Association. Thyroid. 2006;16(10):949-51.

33. Delange F. Iodine requirements during pregnancy, lactation and the neonatal period and indicators of optimal iodine nutrition. Public Health Nutrition. 2007;10(12A):1571-80.

34. Medicine Io. Dietary Reference Intakes for Vitamin A, Vitamin K, Arsenic, Boron, Chromium, Copper, Iodine, Iron, Manganese, Molybdenum, Nickel, Silicon, Vanadium, and Zinc. Washington, DC: The National Academies Press; 2001.

35. Lichtenstein AH, Appel LJ, Brands M, Carnethon M, Daniels S, Franch HA, et al. Diet and Lifestyle Recommendations Revision 2006. Circulation. 2006;114(1):8296.

36. Semba RD, Delange F. Iodine in human milk: perspectives for infant health. Nutrition Reviews. 2001 Aug;59(8 Pt 1):269-78.

37. Azizi F, Smyth P. Breastfeeding and maternal and infant iodine nutrition. Clin Endocrinol (Oxf). 2009;70(5):803-9.

38. Medicine Io. Nutrition During Lactation. Washington, DC: The National Academies Press; 1991.
39. Organization WH. Malnutrition in Women. World Health Organization. Mozambique: Nutrition landascape information system; 2003. p. wabpage.

40. Organization WH. Vitamin and mineral requirements in human nutrition. In: FAO, editor. World Health Organization. $2^{a}$ ed. Geneva, Switzerland: World Health Organization; 2014. p. 362.

41. Bouga M, Lean MEJ, Combet E. Contemporary challenges to iodine status and nutrition: the role of foods, dietary recommendations, fortification and supplementation. Proc Nutr Soc. 2018 Aug;77(3):302-13.

42. Ershow AG, Skeaff SA, Merkel JM, Pehrsson PR. Development of Databases on Iodine in Foods and Dietary Supplements. Nutrients. 2018 Jan 17;10(1).

43. Trumbo PR. FDA regulations regarding iodine addition to foods and labeling of foods containing added iodine. Am J Clin Nutr. 2016 Sep;104 Suppl 3:864S-7S.

44. Network IG. Global map of legislation on salt iodization. Iodine Global Network. Ottawa, Canada: Iodine Global Network; 2018. p. 01.

45. Fund UNCs. Brighter Futures: Protecting early brain development through salt iodization - The UNICEFGAIN Partnership Project. United Nations Children's Fund. $2^{a}$ ed. New York, United States: United Nations Children's Fund; 2018.

46. Zimmermann MB. The impact of iodised salt or iodine supplements on iodine status during pregnancy, lactation and infancy. Public Health Nutr. 2007 2007/00;10(12A):1584-95. 